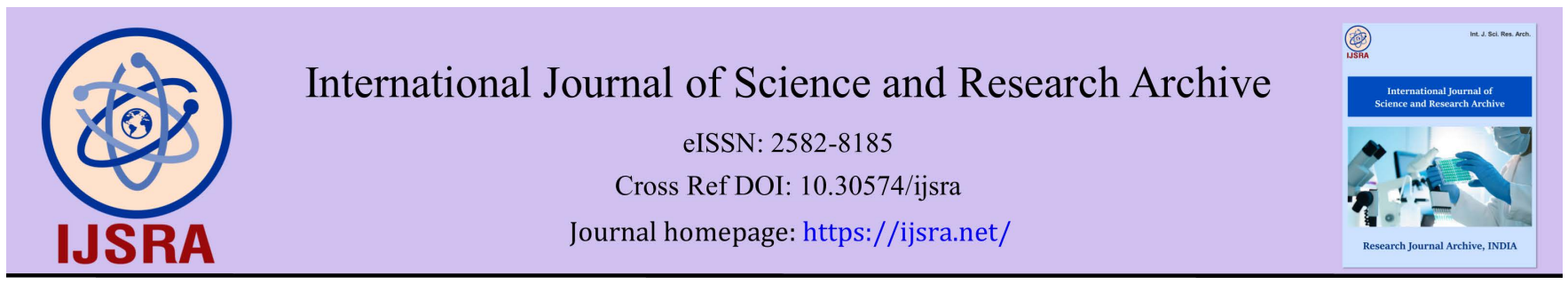

(RESEARCH ARTICLE)

Check for updates

\title{
Phytochemistry and GC-MS Screening and Biocidal Potentiality of Ginger (Zingiber officinale) Rhizome against Mosquito's Larvae
}

\author{
Dalia Mustafa M Elbashir ${ }^{1}$, Mutaman AA Kehail 2, ${ }^{*}$, Abdalla I Abdalla Mohamed ${ }^{3}$ and Abdelmonem Eltiyab H \\ Ali 4
}

1, Dept of Botany, Faculty of Science, University of Gezira, Sudan.

${ }^{2}$ Faculty of Science, University of Gezira, Sudan.

${ }^{3}$ Faculty of Environmental Health Science, University of Gezira, Sudan.

${ }^{4}$ Biology Dept., College of Science, King Khalid University, KSA.

International Journal of Science and Research Archive, 2021, 03(02), 090-096

Publication history: Received on 11 August 2021; revised on 21 September 2021; accepted on 23 September 2021

Article DOI: https://doi.org/10.30574/ijsra.2021.3.2.0137

\begin{abstract}
Mosquitoes can act as vectors for many viruses and parasites through carrying these organisms from person to person. Although great number of natural products are lethal to mosquitoes, but few researches are conducted to understand the magnitude of the behavioral response to these plant parts. The objectives of this study were to screen the phytochemical and other chemical components from ginger rhizome in addition to test their aqueous and ethanol extracts on mosquito's larvae. The standard methods, materials and devices were used to screen the phytochemical components and the chemical constituents (GC-MS). The aqueous and the ethanol extracts from clove pods were prepared and used against Anopheles, Culex and Aedes larvae. The results of the aqueous extract showed that, the $\mathrm{LC}_{50}$ was $153.77 \mathrm{mg} / \mathrm{L}$ for Anopheles larvae, $179.05 \mathrm{mg} / \mathrm{L}$ for Culex larvae, and $208.37 \mathrm{mg} / \mathrm{L}$ for Aedes larvae, also the ethanol extract of ginger rhizome was more potent than the aqueous extract. The biocidal activity can be attributed to the presence of saponins, flavonoids, glycosides, alkaloids and steroids. The GC-MS for the hexane extract showed the presence of alkaloid: gingerol $(18 \%)$ and eugenyl acetate- $(19 \%)$ that gives the sweet aromatic, spicy taste, but the ethanol extract detected gingerol $(43 \%)$ and zingiberene (14\%). The obtained data will be useful to understand the mechanisms and reasons of biocidal activity of ginger rhizome against the tested mosquito's larvae.
\end{abstract}

Keywords: Ginger rhizome; Phytochemistry; GC-MS; Mosquitoes; Natural products

\section{Introduction}

Mosquitoes (Insecta: Diptera) transmit many vector-borne diseases and cause millions of deaths and Health problems every year [1]. Mosquitoes remains the most important vector-borne diseases to most countries of the tropical and subtropical zones. Anopheles is a genus of mosquito involves 460 species, 100 of which can transmit human malaria [2]. Aedes aegypti is the primary vector of dengue fever and is highly anthropophilic. It is found in association with humans and lives where human is found [3]. Culex as an important vector have a broad geographic distribution in the world [4]. Culex involved in transmission of West Nile virus, Sindbis arboviruses, Dirofilariaimmitis and Rift Valley fever virus [5].

Ginger (Zingiber officinale) family Zingiberaceae is an herbaceous perennial flowering plant whose rhizome is widely used as a spice and a folk medicine [6]. It is grows about one meter tall bearing flowers having pale yellow petals with purple edges [7].

${ }^{*}$ Corresponding author: Mutaman AA Kehail

Faculty of Science, University of Gezira, Sudan.

Copyright $(2021$ Author(s) retain the copyright of this article. This article is published under the terms of the Creative Commons Attribution Liscense 4.0. 
Ginger is fragrant kitchen spice [8] and it used worldwide; whether it be used to spice up meals, or as a medicine, the history of needs for ginger has been recorded [9]. Ginger also used as vegetables, candy, soda and alcoholic beverages [10].

The volatile oils compose 1-3\% of the weight of fresh ginger, and it consist of zingerone, shogaols, and gingerols as the major pungent compound. Zingerone have lower pungency and a spicy-sweet aroma. Shogaols are more pungent and higher antioxidant activity [11].

The lethal activity of some natural products against insects has been tested in different parts of world specially against mosquito's larvae and the other important vectors that transmit infectious disease agents. Prevention of some disease remains almost entirely dependent on vector control, which is considered to be the most effective method for reducing disease transmission in all areas of the world [12].

The present study aims to evaluate the biocidal activity of $Z$, officinale (ginger) aqueous and ethanol extract against $A n$. arabiensis, Cx. quinquefasciatus, and Ae. aegypti larvae under laboratory conditions. The study also evaluate the phytochemical and GC-MS output for the used ginger rhizome part.

\section{Material and methods}

The samples of ginger (Z. officinale) rhizome, were brought from the local market of Wad Medani City, whereas the An. arabiensis, CX. quinquefasciatus, and Ae. aegypti larvae were collected from Tayba village, Gezira State, by an expert technician.

\subsection{Preparation of extracts}

The ginger rhizome was brought from the local market and was cleaned manually, then cut into small parts and let to dry at room temperature away from direct sunlight, then crushed after several days to fine granules. A well calculated amount of the granules was extracted with water, 99\% ethanol and hexane. The water and the ethanol extracts were used for the biocidal tests, while ethanol and hexane extracts were used in GC-MS tests.

\subsection{Phytochemical screening}

The crushed granules of ginger rhizome was used as a raw materials for the qualitative phytochemical screening tests following Uraku [13], so as to determine the presence (+) or absence (-) of some of the main classes, viz, alkaloids, glycosides, tannins, flavonoids, saponins and steroids.

\subsection{GC-MS test}

This test was done in the Central Lab., University of Gezira, Gezira State, Sudan. The ethanol and hexane extracts were tested using GC-MS methods. The chromatograph, retention time, peak, \% area, the chemical formula and the molecular weight of the identified components were provided by the NIST library database,

\subsection{Biocidal tests}

The susceptibility An. arabiensis, Cx. quinquefasciatus and Ae. aegypti larvae were tested following the instructions of WHO [14]. The test period was 24 hours and based on three replicates. Control batch was also designed. The field collected larvae of the three species were separated in three small dishes and were immediately tested for their susceptibilities. The accidentally collected aquatic organisms were immediately eliminated.

\subsection{Data analysis}

Following Abbott [15] and Finney [16], the log-concentrations and the corresponding tested mortalities were used to run the Probit analysis. The diagnostic doses ( $\mathrm{LC}_{50}$ and $\mathrm{LC}_{95}$ ) of the aqueous and the ethanol extracts of ginger rhizome against the tested mosquito larvae were calculated from the regression equation. 


\section{Results and discussion}

\subsection{Phytochemical screening}

Table (1) showed the presence of saponins, flavonoids, glycosides, alkaloids and steroids in ginger rhizome dried powder, but tannins were not detected. Geographical differences were appeared from the obtained results when compared to the results of other research areas of the world.

Rhizome of Z. officinale obtained from University of Calabar Botanical Garden, Nigeria, showed the presence of alkaloids, saponins, flavonoids, polyphenols, cardiac glycosides and reducing sugars were present in both the aqueous extract and petroleum ether extract. While tannins, phlobatannins, anthranoids, hydroxyl anthroquinones and anthraquinones were absent in both aqueous and petroleum ether extracts [17]. Phytochemical screening of ginger from Punjab, Pakistan, showed presence of alkaloid, phlobotannins, flavanoids, glycosides, saponins, tannin and terpenoids and absence of steroids [18].

Table 1Phytochemical screening of the main classes in ginger rhizome

\begin{tabular}{|l|c|}
\hline \multicolumn{1}{|c|}{ Main class } & Status \\
\hline Saponins & + \\
\hline Flavonoids & + \\
\hline Tannins & - \\
\hline Glycosides & + \\
\hline Alkaloids & + \\
\hline Steroids & + \\
\hline
\end{tabular}

(-) Means absence of the main class; $(+)$ mean presence of the main class

\subsection{GC-MS test}

Table 2 Compounds identified by GC-MS from the hexane extract of ginger rhizome

\begin{tabular}{|c|c|c|l|c|c|}
\hline Peak & R. time & Area\% & Name & Mol. form. & Mol. wt \\
\hline 1 & 4.264 & 1.71 & Hexane,2-Nitro & $\mathrm{C}_{6} \mathrm{H}_{13} \mathrm{O}_{2}$ & 131 \\
\hline 2 & 5.704 & 1.43 & Octanal & $\mathrm{C}_{8} \mathrm{H}_{16} \mathrm{O}$ & 128 \\
\hline 3 & 9.196 & 4.27 & Decanal & $\mathrm{C}_{16} \mathrm{H}_{20} \mathrm{O}$ & 156 \\
\hline 4 & 11.586 & 1.58 & Phenol,2-methoxy-3-(2-propenyl)- & $\mathrm{C}_{10} \mathrm{H}_{12} \mathrm{O}_{2}$ & 164 \\
\hline 5 & 13.948 & 1.47 & Phenol,2-methoxy-4-(2-propenyl)-acetate & $\mathrm{C}_{12} \mathrm{H}_{14} \mathrm{O}_{3}$ & 206 \\
\hline 6 & 15.705 & 18.07 & Gingerol & $\mathrm{C}_{17} \mathrm{H}_{26} \mathrm{O}_{4}$ & 244 \\
\hline 7 & 18.075 & 2.56 & Hexacosane & $\mathrm{C}_{26} \mathrm{H}_{54}$ & 366 \\
\hline 8 & 19.265 & 1.42 & Hexacosane & $\mathrm{C}_{26} \mathrm{H}_{54}$ & 366 \\
\hline 9 & 19.566 & 2.20 & 1,2 -Benzenedicarboxylic acid,butyl 8-methyl & $\mathrm{C}_{22} \mathrm{H}_{34} \mathrm{O}_{4}$ & 362 \\
\hline 10 & 19.812 & 2.82 & 1 -(+)-Ascorbic acid 2,6-dihexadecanoate & $\mathrm{C}_{38} \mathrm{H}_{68} \mathrm{O}_{8}$ & 652 \\
\hline 11 & 20.163 & 1.84 & Hexadecanoic acid, ethyl ester & $\mathrm{C}_{18} \mathrm{H}_{36} \mathrm{O}_{2}$ & 284 \\
\hline 12 & 20.405 & 1.82 & Hexacosane & $\mathrm{C}_{26} \mathrm{H}_{5}$ & 366 \\
\hline 13 & 22.423 & 4.62 & Furan, 2,5-dibutyl- & $\mathrm{C}_{12} \mathrm{H}_{20} \mathrm{O}$ & 180 \\
\hline 14 & 23.149 & 13.74 & Eugenyl acetate & $\mathrm{C}_{12} \mathrm{H}_{14} \mathrm{O}_{3}$ & 206 \\
\hline 15 & 24.006 & 1.35 & Undecane, 1-bromo- & $\mathrm{C}_{11} \mathrm{H}_{23} \mathrm{Br}$ & 235 \\
\hline
\end{tabular}




\begin{tabular}{|c|c|c|l|c|c|}
\hline 16 & 25.050 & 2.99 & Naphthalene- decahydro-1-pentadecyl- & $\mathrm{C}_{25} \mathrm{H}_{48}$ & 348 \\
\hline 17 & 225.470 & 4.54 & Diisooctyl phthalate & $\mathrm{C}_{24} \mathrm{H}_{38} \mathrm{O}_{4}$ & 390 \\
\hline 18 & 25.997 & 5.24 & Eugenyl acetate & $\mathrm{C}_{12} \mathrm{H}_{14} \mathrm{O}_{3}$ & 206 \\
\hline 19 & 26.830 & 4.44 & 2,6,6-trimethylcyclohex-1-enylmethanesulfo & $\mathrm{C}_{16} \mathrm{H}_{22} \mathrm{O}_{2} \mathrm{~S}$ & 278 \\
\hline 20 & 27.321 & 3.61 & 13-Docosamide, (Z) & $\mathrm{C}_{22} \mathrm{H}_{43} \mathrm{NO}$ & 337 \\
\hline
\end{tabular}

Table (2) showed that, about 20 different compounds were identified through GC-MS from the hexane extraction of ginger rhizome. The principal compound was the alkaloid: gingerol (18\%) and eugenyl acetate- $(19 \%)$ which gives the sweet aromatic, spicy taste. Table (3) showed that, about 20 different compounds were identified from the ethanol extract, within which gingerol (43\%) is the main principle. Terpenes (isoborneol and alpha-terpineol) were detected in small amount (1.6\% and $0.57 \%$, respectively). Zingiberene (14\%) and other sesquiterpenes (beta-bisabolene (3.44\%); Cyclohexaene, 3-1,5-dimethyl-4-hexenyl (6.69\%) and Dihydrocarvyl acetate (which act as flavor ingredient because it has a minty taste and usually used as one of the food additives) were also detected.

Ginger rhizome from Eastern part of Nigeria, showed the presence of Gingerol at Peak 12 and Ricinoleic acid at the last [19]. GC-MS analysis of methanol extract of $Z$. officinale rhizomes from India, detected Zingiberene, AR-curcumene, $\alpha$ Bergamotene, Gingerol, Zingerone, Caryophyllene and ç-Elemene [20].

Table 3 Compounds identified by GC-MS from the ethanol extract of ginger rhizome

\begin{tabular}{|c|c|c|l|c|c|}
\hline Peak & R. time & Area\% & \multicolumn{1}{|c|}{ Name } & Mol. form. & Mol. wt \\
\hline 1 & 4.399 & 0.69 & Dihydrocarvyl acetate & $\mathrm{C}_{12} \mathrm{H}_{20} \mathrm{O}_{2}$ & 196 \\
\hline 2 & 5.421 & 2.39 & Exo-2,7,7-trimethylbicyclo [2,2,1] heptan-2-ol & $\mathrm{C}_{10} \mathrm{H}_{18} \mathrm{O}$ & 154 \\
\hline 3 & 7.079 & 1.62 & isoborneol & $\mathrm{C}_{10} \mathrm{H}_{18} \mathrm{O}$ & 154 \\
\hline 4 & 7.335 & 0.57 & Alpha-terpineol & $\mathrm{C}_{10} \mathrm{H}_{18} \mathrm{O}$ & 154 \\
\hline 5 & 7.516 & 1.41 & Butanedioic acid, 2,3-bis(acetyloxy)-[R-(R & $\mathrm{C}_{8} \mathrm{H}_{10} \mathrm{O}_{8}$ & 178 \\
\hline 6 & 8.237 & 0.76 & Benzeneethanamine, 2,5-dimethoxy-alpha & $\mathrm{C}_{11} \mathrm{H}_{17} \mathrm{NO}_{2}$ & 195 \\
\hline 7 & 9.075 & 1.74 & Phenol, 2-methoxy-3-(2-propenyl)- & $\mathrm{C}_{10} \mathrm{H}_{12} \mathrm{O}_{2}$ & 164 \\
\hline 8 & 10.546 & 4.65 & Benzene, 1-(1,5-dimethyl-4-hexenyl)-4-meth & $\mathrm{C}_{15} \mathrm{H}_{22}$ & 202 \\
\hline 9 & 10.711 & 14.04 & Zingiberene & $\mathrm{C}_{15} \mathrm{H}_{24}$ & 204 \\
\hline 10 & 10.860 & 3.44 & Beta-bisabolene & $\mathrm{C}_{15} \mathrm{H}_{24}$ & 202 \\
\hline 11 & 11.001 & 6.69 & Cyclohexaene, 3-(1,5-dimethyl-4-hexenyl)- & $\mathrm{C}_{15} \mathrm{H}_{24}$ & 204 \\
\hline 12 & 11.704 & 7.96 & Beta-D-glucopyranose, 4-0-beta-D-galactose & $\mathrm{C}_{12} \mathrm{H}_{22} \mathrm{O}_{11}$ & 342 \\
\hline 13 & 11.973 & 1.44 & Pregan-20-one, 2-hydroxy-5,6-epoxy-15-met & $\mathrm{C}_{22} \mathrm{H}_{34} \mathrm{O}_{3}$ & 346 \\
\hline 14 & 12.554 & 1.51 & 6,10-Dodecadien-1-yn-3-ol, 3,7,11-trimethyl- & $\mathrm{C}_{15} \mathrm{H}_{24} \mathrm{O}$ & 220 \\
\hline 15 & 13.503 & 1.87 & Farnesyl acetone & $\mathrm{C}_{18} \mathrm{H}_{20} \mathrm{O}$ & 262 \\
\hline 16 & 14.894 & 1.02 & 2,4-bis(hydroxyamino)-5-nitropyrimidine & $\mathrm{C}_{6} \mathrm{H}_{6} \mathrm{~N}_{2} \mathrm{O}_{2} \mathrm{~S}_{2}$ & 348 \\
\hline 17 & 15.201 & 2.07 & Docosanoic acid, ethyl ester & $\mathrm{C}_{24} \mathrm{H}_{34} \mathrm{O}_{2}$ & 356 \\
\hline 18 & 16.584 & 2.22 & E-11-hexadecenoic acid, ethyl ester & $\mathrm{C}_{18} \mathrm{H}_{34} \mathrm{O}_{2}$ & 282 \\
\hline 19 & 16.892 & 0.57 & 1-(5-bicyclo [2,2,1] heptyl)ethylamine & $\mathrm{C}_{9} \mathrm{H}_{17} \mathrm{~N}$ & 139 \\
\hline 20 & 17.309 & 43.02 & Gingerol & $\mathrm{C}_{17} \mathrm{H}_{26} \mathrm{O}_{4}$ & 244 \\
\hline
\end{tabular}




\subsection{Biocidal tests}

Table (4) showed that, the aqueous extract of ginger rhizome was tested at concentrations of $80.54-177.19 \mathrm{mg} / \mathrm{L}$ for a period of 24 hours against Anopheles, Culex and Aedes larvae. The results showed that, at the minimum concentration (80.54 mg/L), 10\% of Anopheles larvae were killed, while 20\% of Culex and Aedes were killed. At the higher concentration (177.19 mg/L), the mortality of mosquito's larvae ranged between 50\% (in Aedes) to 65\% (in Anopheles). The LC50 was $153.77 \mathrm{mg} / \mathrm{L}$ for Anopheles larvae, $179.05 \mathrm{mg} / \mathrm{L}$ for Culex larvae, and $208.37 \mathrm{mg} / \mathrm{L}$ for Aedes larvae, hence, Anopheles larvae was relatively more susceptible to the aqueous extract of ginger rhizome than the other two species of mosquitoes, while Aedes larvae showed respectively more resistance to the same aqueous extract. The LC95 confirm the same conclusion. It was noticed that, the control mortality was 0 . The polar content of ginger rhizome was $12.45 \%$.

Table 4 Percentage mortality of mosquito's larvae subjected to aqueous extract of ginger rhizome after 24 hrs

\begin{tabular}{|c|c|c|c|c|c|c|c|}
\hline \multicolumn{2}{|c|}{ Concentration } & \multicolumn{3}{|c|}{ Corrected Mortality } & \multicolumn{3}{|c|}{ Probit } \\
\hline $\mathrm{mg} / \mathrm{L}$ & Log & Anopheles & Culex & Aedes & Anopheles & Culex & Aedes \\
\hline 80.54 & 1.91 & 10 & 20 & 20 & 3.72 & 4.16 & 4.16 \\
\hline 112.76 & 2.05 & 15 & 30 & 30 & 3.96 & 4.48 & 4.48 \\
\hline 128.88 & 2.11 & 42.5 & 35 & 35 & 4.82 & 4.61 & 4.61 \\
\hline 161.08 & 2.21 & 50 & 40 & 35 & 5.00 & 4.75 & 4.61 \\
\hline 177.19 & 2.25 & 65 & 55 & 50 & 5.41 & 5.13 & 5.00 \\
\hline \multicolumn{8}{|c|}{ Probit analysis } \\
\hline \multicolumn{5}{|l|}{$\mathrm{R}^{2}$} & 0.90 & 0.92 & 0.86 \\
\hline \multicolumn{5}{|c|}{ Intercept } & -6.00 & -0.70 & 0.20 \\
\hline \multicolumn{5}{|l|}{ Slope } & 5.03 & 2.53 & 2.07 \\
\hline \multicolumn{5}{|c|}{$\mathrm{LC}_{50}(\mathrm{mg} / \mathrm{L})$} & 153.77 & 179.05 & 208.37 \\
\hline \multicolumn{5}{|c|}{$\mathrm{LC}_{95}(\mathrm{mg} / \mathrm{L})$} & 325.78 & 796.50 & 1291.55 \\
\hline
\end{tabular}

Table (5) showed that, the ethanol extract of ginger rhizome was tested at concentrations of $55.32-183.34 \mathrm{mg} / \mathrm{L}$ for a period of 24 hours against Anopheles, Culex and Aedes larvae. At the minimum concentration (55.32 mg/L), 90\% of Anopheles, 50\% Culex larvae and 45\% of Aedes larvae were died. At the higher concentration (183.34 mg/L), the mortality of mosquito's larvae ranged between 100\% (in Anopheles) to 75\% (in Aedes). The LC50 was not detected for Anopheles larvae (because there were only two values of mortality bellow $100 \%$ which were not sufficient to perform Probit analysis), but it was $56.11 \mathrm{mg} / \mathrm{L}$ for Culex larvae and $63.97 \mathrm{mg} / \mathrm{L}$ for Aedes larvae, hence, Anopheles larvae was relatively more susceptible to the ethanol extract of ginger rhizome than the other two species of mosquitoes. while Aedes larvae showed respectively more resistance to ginger rhizome ethanol extract. LC 95 values also confirm the same conclusion. According to the LC's values, it was clear that, the ethanol extract of ginger rhizome was more potent than the aqueous extract. It was noticed that, the control mortality was 0 . The polar content of ginger rhizome was $14.90 \%$.

Insecticidal activity of ginger and Eucalyptus essential oils against adult form of Culex theileri mosquitoes, collected from small pools located near the Zayande-Rood River, Iran, were examined via direct exposure method. Results show considerable values of insecticidal activity against mosquitoes. Eucalyptus globulus (66\% insecticidal activity) was more potent than Z. officinale (45\% insecticidal activity). This study shows that these essential oils can be considered as good replaces for chemical pesticides [5].

Ginger among other plants e.g. Aloe vera, garlic and datura can be recommended for use in mosquito management programs as potential alternatives to synthetic insecticides [21]. Ginger essential oils possess good larvicidal, repellant, and antimicrobial activity [22]. 
Table 5 Percentage mortality of mosquito's larvae subjected to ethanol extract of ginger rhizome after 24 hrs

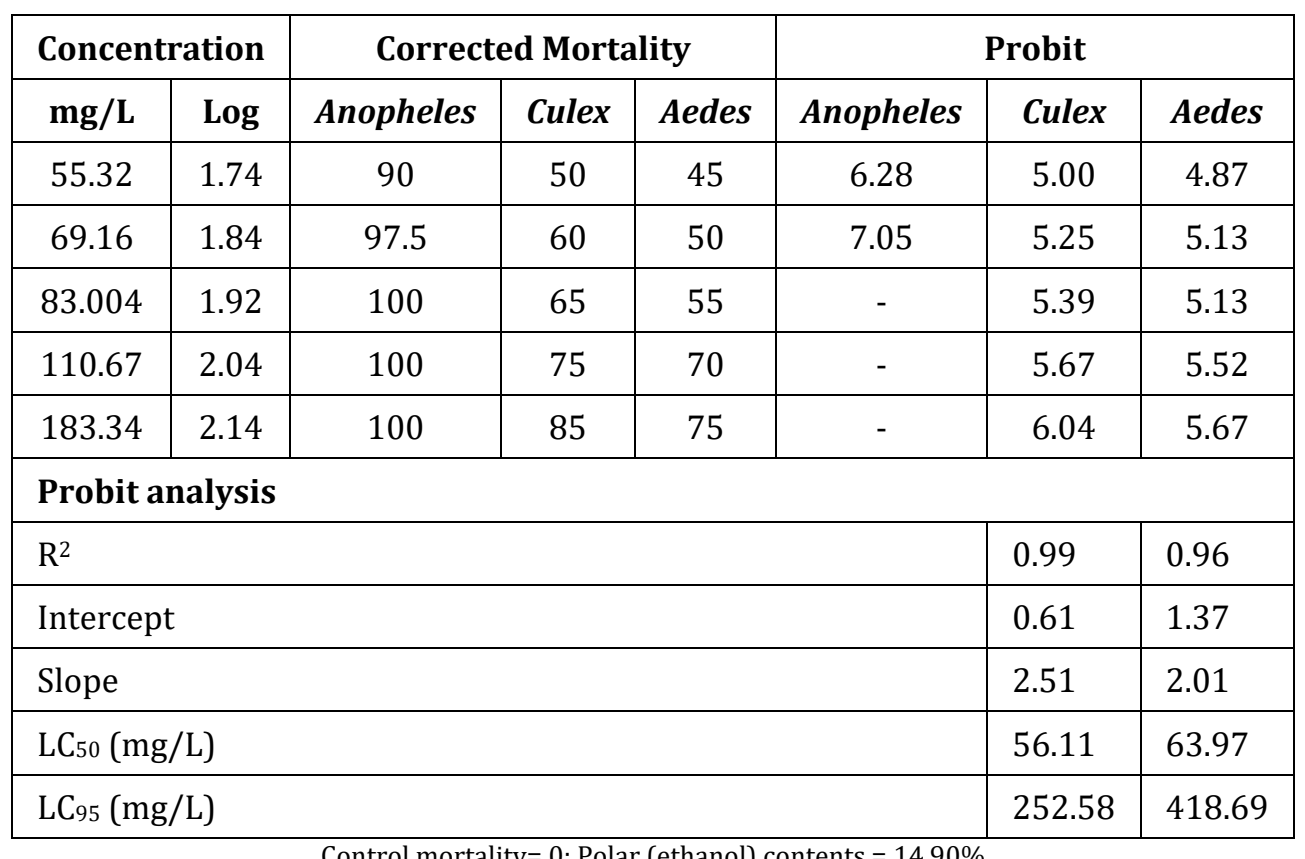

\section{Conclusion}

Ginger rhizome contains saponins, flavonoids, glycosides, alkaloids and steroids.

GC-MS for the hexane extraction of ginger rhizome, detected the alkaloid: gingerol (18\%) and eugenyl acetate- (19\%). Gingerol (43\%), Zingiberene (14\%) and other sesquiterpenes (beta-bisabolene (3.44\%); Cyclohexaene, 3-1,5-dimethyl4-hexenyl (6.69\%) were detected through GC-MS from ginger rhizome ethanol extract.

The $\mathrm{LC}_{50}$ for ginger rhizome aqueous extract was $153.77 \mathrm{mg} / \mathrm{L}$ for Anopheles larvae, $179.05 \mathrm{mg} / \mathrm{L}$ for Culex larvae, and $208.37 \mathrm{mg} / \mathrm{L}$ for Aedes larvae.

Anopheles larvae were relatively more susceptible to the aqueous extract of ginger rhizome than the other two species of mosquitoes.

The ethanol extract of ginger rhizome was more potent than the aqueous extract.

\section{Compliance with ethical standards}

\section{Acknowledgments}

Thanks, are for the staff of Food Analysis Lab., Faculty of Engineering and Technology; Central Lab., University of Gezira; and Blue Nile National Institute for Communicable Disease, University of Gezira.

\section{Disclosure of conflict of interest}

The authors (Dalia, Mutaman, Abdalla and Abdelmonem) declare no conflicts of interest regarding the publication of this paper.

\section{Statement of ethical approval}

The present research work does not contain any studies performed on animals/humans subjects by any of the authors.

\section{References}

[1] WHO. Pesticides and Their Application for the Control of Vectors and Pests of Public Health Importance. Geneva, Switzerland. 2006. 
[2] Yoshida S, Shimada Y, Kondoh D, Kouzuma Y, Ghosh AK, Jacobs-Lorena M, Sinden RE. Hemolytic C-type lectin CEL-III from sea cucumber expressed in transgenic mosquitoes impairs malaria parasite development. PLOS Pathogens. 2007; 3(12): e192.

[3] Chan KL, Ho BC, Chan YC. Aedes aegypti (L.) and Aedes albopictus (Skuse) in Singapore City. 2. Larval habitats. Bull. Wld. Hlth. Org. 1971; 44: 629-633.

[4] Demirci B, Lee Y, Lanzaro GC, Alten B. Identification and characterization of single nucleotide polymorphisms (SNPs) in Culex theileri (Diptera: Culicidae). 2012, Journal of Medical Entomology. 2012; 49: 581-588.

[5] Madreseh-Ghahfarokhi S, Pirali Y, Dehghani-Samani A, Dehghani-Samani A. The insecticidal and repellent activity of ginger (Zingiber officinale) and eucalyptus (Eucalyptus globulus) essential oils against Culex theileri Theobald, 1903 (Diptera: Culicidae). Annals of Parasitology. 2018; 64(4): 351-360.

[6] NCCIH, National Center for Complementary Integrative Health. Ginger, NCCIH Herbs at a Glance". 2016.

[7] Sutarno H, Hadad EA, Brink M. Zingiber officinale Roscoe. In De Guzman CC, Siemonsma JS (eds.). Plant resources of South-East Asia: no.13: Spices. Leiden (Netherlands): Backhuys Publishers. 1999; 238-244.

[8] Kew Science. Zingiber officinale Roscoe.Plants of the World Online. Royal Botanic Gardens. Retrieved 25 November 2017.

[9] Ravindran PN. Introduction: Ginger. CRC Press. 2016; 16-29.

[10] Nair KP. Ginger as a Spice and Flavorant, Turmeric (Curcuma longa L.) and Ginger (Zingiber officinale Rosc.) World's Invaluable Medicinal Spices, Springer International Publishing. 2019; 541-554.

[11] An K, Zhao D, Wang Z. Comparison of different drying methods on Chinese ginger (Zingiber officinale Roscoe): Changes in volatiles, chemical profile, antioxidant properties, and microstructure. Food Chem. 2016, 197(Part B): 1292-1300.

[12] Grieco JP, Achee NL, Chareonviriyaphap T, Suwonkerd W, Chauhan K, Sardelis MR, Roberts DR. A new classification system for the actions of IRS chemicals traditionally used for malaria control. 2007: 2(8): e716.

[13] Uraku AJ. Phytochemical evaluation of Ocimum basilicum (Sweet basil) leaves collected from Abakaliki-Nigeria, using Gas chromatography-Mass Spectrometry. Adv. Biomed. Pharma. 2016; 3(1): 46-58.

[14] WHO. Report of the WHO informal consultation on the evaluation on the testing of insecticides. CTD/WHO PES/IC/. 1996; 96(1): 69.

[15] Abbott WS. A method of computing the effectiveness of an insecticide. J. Econ. Entomol. 1925; 18: 265-267.

[16] Finney DJ. Probit Analysis: A Statistical Treatment of the Sigmoid Response Curves. 3rded. Cambridge, UK: Cambridge University Press. 1971.

[17] Osabor VN, Bassey FI, Umoh UU. Phytochemical Screening and Quantitative Evaluation of Nutritional Values of Zingiber officinale (Ginger). American Chemical Science Journal. 2015; 8(4): 1-6.

[18] Riaz H, Begum A, Raza SA, Khan ZM, Yousaf H, Tariq A. Antimicrobial property and phytochemical study of ginger found in local area of Punjab, Pakistan. International Current Pharmaceutical Journal. 2015; 4(7): 405-409.

[19] Chinonye II, Oze RN, Lynda OU, Nkwoada A, Adanma AU. Phytochemical and GC/MS Analysis of the Rhizome of Zingiber officinale Plant Grown in Eastern Part of Nigeria. African Journal of Biology and Medical Research. 2018; 1(1): 43-54.

[20] Choudhari SS, Kareppa BM. Identification of Bioactive Compounds of Z. Officinale Roscoe Rhizomes through Gas Chromatography and Mass Spectrometry. Intern. J. Pharmac. Res. and Development. 2013; 5(8): 16 - 20.

[21] Iqbal J, Ishtiaq F, Alqarni AS, Owayss AA. Evaluation of larvicidal efficacy of indigenous plant extracts against Culex quinquefasciatus (Say) under laboratory conditions. Turk J. Agric. Forestry. 2018; 42: 207-215.

[22] Hazarika H, Boruah S, Islam J, Paul A, Zaman MK. Antimicrobial, Mosquito Larvicidal and Repellent Activity of Essential Oils Isolated from Three Local Species of Ginger Grown in Upper Assam Region, India. Current Trends in Pharmaceutical Research. 2020; 7(1): 126-142. 